\title{
LOAN AFFIXES \\ IN HUNGARIAN WORD FORMATION: REGULARITY, PRODUCTIVITY, RIVALRY*
}

\author{
MÁRIA LADÁNYI \\ Department of Applied Linguistics \\ Eötvös Loránd University \\ Múzeum krt. 4/D \\ H-1088 Budapest \\ Hungary \\ ladanyi.maria@iif.hu
}

\begin{abstract}
This paper explores the (degree of) productivity of some loan affixes deriving nouns on the basis of a relatively large amount of corpus data, starting from the Natural Morphology approach to productivity. The two criteria originally proposed in that framework with respect to loan affixes do not seem to be sufficient for establishing the productivity of a given affix, whereas the more sophisticated productivity criteria applicable to native affixes are incapable of properly indicating the degrees of productivity in the case of loan affixes. In the paper, we propose a system of criteria for the productivity scale of loan affixes in Hungarian on the basis of the data considered, and evaluate the loan affixes studied in terms of their productivity and its degree. On the other hand, with the affixes discussed here as well as the material of other productivity studies and other functional considerations in mind, we conclude, departing from the usual approach within Natural Morphology, that the size of the domain of rule application and type frequency also play a role in the emergence and maintenance of productive rules and in the fate of the degree of productivity of the individual affixes.
\end{abstract}

Keywords: Ioan affixes, Natural Morphology, productivity criteria, type frequency, domain of word formation rules

\section{Introduction}

The present paper explores the degree of productivity of a number of loan affixes deriving nouns in Hungarian with a relatively large body of

* My thanks are due to members of the Functional linguistics workshop of Eötvös Loránd University, Budapest, for their useful comments on a preliminary version of this paper. 
data $^{1}$ taken into consideration. Our approach to productivity will rely on that of Natural Morphology (cf. Dressler-Ladányi 1998; 2000) as a point of departure. Part of the reason why we have embarked on this project is that the descriptive literature on present-day Hungarian includes very little discussion of derivational affixes borrowed from other languages and even the few claims that can be found are inconsistent or controversial (cf. section 4 below) since they are not based on a sufficient amount of reliable data. On the other hand, an investigation of the productivity of loan affixes will also prove to be fruitful from a theoretical point of view. One of the issues they raise concerns the degrees of their productivity. Whereas Natural Morphology provides us with a sophisticated system of criteria for establishing degrees of productivity with respect to native affixes, the two criteria originally proposed in that framework for loan affixes appear to be insufficient. A better, more fine-grained set of specific criteria is therefore necessary for the evaluation of the productivity of loan affixes. Another theoretical problem that can be discussed on the basis of this relatively large body of data is not specific to loan affixes but concerns productivity in word formation in general: this is the issue of the relationship of type frequency, domain of rule application, and productivity.

\section{Productivity and its degrees}

\subsection{The concept of productivity}

The concept of productivity in morphology has received a lot of attention recently, both in a theoretical and in an empirical perspective (cf., e.g., Dressler 1997; Baayen 1989; Lieber-Baayen 1993; Plag 1999; Plag et al. 1999; Dressler-Ladányi 1998; 2000; Bauer 1983; 2001; 2005). Rule-based theories of morphology (including Natural Morphology) construe 'morphological productivity' as a typical property of morphological rules (cf. Bauer 2001, 12-5), ${ }^{2}$ while in Plag's (1999) view the aim of morphology

${ }^{1}$ I wish to express my gratitude to Viktor Nagy for having electronically gleaned the lexical data used in this paper from two subcorpora ("press" and "index") of the Hungarian National Corpus (HNC) and for making occurrence lists and concordances of the suffixes studied here available for me.

${ }^{2}$ A large subset of modern theories of morphology (just like a large subset of modern theories of linguistics in general) is rule-based. The reason is that setting 
as a theory is itself intimately bound up with productive rules and possible words of the given language. ${ }^{3}$ The concept of productivity equally applies to both inflectional and derivational morphology - though in the present paper, due to its specific topic, we will only be concerned with productivity in word formation.

In rule-based models of morphology, the systematic application of productive word formation rules is responsible for possible words of a language, also referred to as 'potential words'. The notion of potential word helps us model an open-ended-continually increasing - part of the word stock. In particular, the part in which non-lexicalised, morphologically complex, potential words of the given language may come into existence on the basis of productive patterns that can be formalised in terms of rules that freely apply to members of one or several open lexical class (es). ${ }^{4}$ In addition, productive rules are characterised by the fact that no conscious effort is involved in their application (as opposed to extramorphological or extragrammatical means of word formation ${ }^{5}$ or non-

up rules presupposes a high degree of generality, and the level of generality that can be achieved is an important criterion in theoretical models of language in general. As opposed to rule-based approaches, connectionist models eschew the use of rules as distinct from lexical items and build their claims on analogical relations within the mental lexicon seen as a rich network of lexical connections (e.g., Bybee 1988; 2006; 2007). Components of a lexical network have various types of analogical relations with one another; and analogical relations characteristic of individual groups of lexical items represent schemes of various strengths that can serve as models for further analogical processes. Description in terms of schemes, then, is Bybee's alternative to description in terms of rules. In the emergence and maintenance of schemes, Bybee attributes an important role to both type and token frequency (cf. also Tanos 2008).

3 "The central aim of general morphological theory is to define the notion of "possible complex word in natural language' or [...] 'in language A'" (ibid., 5). Productive processes necessarily have great significance for language, whether they are accounted for by rules or (as in non-rule-based morphology) by patterns or schemes.

${ }^{4}$ It is accidental which potential words get actualised (occur in actual language use) on the basis of such structures. On the other hand, potential words that can be regularly formed at the systematic level sometimes cannot be actualised because the lexicon already includes a word of the same meaning that represents an obstacle for the application of the rule. This is the phenomenon of lexical blocking (cf. Aronoff 1976; Rainer 1988; 2005; Kiefer-Ladányi 2000a, 157-8).

${ }^{5}$ Extragrammatical morphological operations are called extragrammatical because words created by them do not meet the rules and principles governing 'grammatical morphology' (cf. Dressler 2000). (Results of) such operations are 
productive rules whose application requires creativity and conscious effort on the part of the speaker and makes an impression of playfulness on the listener - cf. Baayen 1989, 11). A classical definition of productivity summarises the above points: "the possibility available to language users to coin, unintentionally, in principle enumerable infinite sets of morphologically complex words by means of the word formation rules of their language" (Schultink 1962; English translation from Baayen 1989, 11).

Of course, the word stock of a language can be increased by other means, not just by word formation; and word formation itself has extramorphological or extragrammatical ways, too (see footnote 5); but in rule-based morphologies the most important tools of creating new words or word forms are productive word formation rules modelling the possible words of a language: these provide speakers with a fundamental part of the ongoing enrichment of the word stock (cf. Dressler-Ladányi 1998; 2000; see also the quote from Plag (1999) in footnote 3 above).

\subsection{Productivity in Natural Morphology}

The literature includes both qualitative and quantitative approaches to productivity. Natural Morphology, our point of departure in this paper, is a rule-based theory of morphology (Dressler et al. 1987; Dressler 1997; 1999) viewing productivity as a system level potentiality. ${ }^{6}$ The theory claims that this qualitative concept of productivity cannot be equated with the quantitative concept of productivity since it cannot be derived either from type frequency or from token frequency; on the contrary, the latter two concepts follow from productivity as potentiality. ${ }^{7}$ Natural Morphology distinguishes the linguistic system, the linguistic norm of the

e.g., intentional abbreviations (clipping: flu< influenza, chute $<$ parachute; initialisms: $P C<$ personal computer, U.N.<United Nations; acronyms: laser $<$ light amplification by stimulated emission of radiation, surfactant $<$ surface active agent, morphological blends: aerobicise < aerobics $\&$ exercise, infomercial $<$ information $\mathcal{E}$ commercial), language games, poetic occasionalisms, etc.

${ }^{6}$ The concept of productivity is similar in this respect in any rule-based morphology; cf. the claim in Kiefer-Ladányi (2000a, 149) that productive derivation necessarily follows a regular pattern (one that can be formalised in a rule) and has to be freely applicable to members of an open class or several open classes, while the meanings of the derived items are compositional, that is, they can be computed and predicted from the meanings of the given base and affix.

7 The issue of type frequency is related to the domain of productive rules, or rather to the size of that domain, too: hence, the relationship between productivity and 
community, and the language use of the individual, and it locates productivity as potentiality within the linguistic system, type frequency within the linguistic norm, and token frequency within the level of individual language use (cf. Dressler-Ladányi 2000, 104).

Natural Morphology takes productivity (just like other similar concepts) to be a gradual or scalar phenomenon; but it maintains that the degrees of productivity of an inflectional class or a derivational pattern cannot be established in terms of the size of the relevant domain (cf. Booij 1977) or in terms of the ratio between possible bases and derivates (cf. Spencer 1991; Katamba 1993) — rather, they can be defined in terms of the difficulty that the given morphological operation has to face. A system of criteria concerning degrees of productivity both for inflection and for derivation within this framework has been proposed by Wolfgang Dressler (1997; Dressler-Ladányi 1998; 2000).

Whereas for native derivational affixes there is a rich array of criteria for establishing their degrees of productivity (cf. Dressler-Ladányi 1998, 39-45; 2000, 119-27; Ladányi 2007, 47-51; 2008, 361-5), the two criteria originally proposed within Natural Morphology for loan affixes (cf. Dressler-Ladányi 1998, 45-6; 2000, 131-2), that is, (1) their ability of fitting loanwords derivationally into the lexicon (e.g., spontane-itás 'spontaneity' < German Spontaneität), and (2) their applicability to loanwords that already fit the system (e.g., tumor-ista 'tumorist' < tumor 'tumour') do not seem to be sufficient for establishing their degree of productivity since some of these loan suffixes occur on native stems, too; what is more, some loan affixes systematically cooccur with certain groups of native stems. On the other hand, the much more refined productivity criteria proposed for native affixes are unable to indicate the relevant degrees of productivity in this case, either in terms of their rank order or with respect to their content. In other words, we need a specific and more sophisticated set of criteria for loan affixes.

\section{Material}

In order to establish the existence (or lack) of the productivity of the affixes under study here, we will consider whether they are regular (i.e.,

type frequency cannot be severed from that between productivity and size of domain. We will return to this in section $\mathbf{6}$ below. 
can be stated in a rule) as a first step. This is because, as it follows from what was stated so far, productivity implies regularity.

This study relies on data gleaned from two subcorpora of HNC ('index', 'press'); that is, on words actually occurring in language use, rather than on constructed examples. This has several reasons. On the one hand, we endorse the tendency characterising functional theories of language that they take language use, usually neglected by formal theories, into consideration both in description and in theorising, even if to different extents in the various models. Apart from corpus linguistics, it was in functional approaches that the notion of usage-based models, as well as efforts to construct such grammars, appeared and gained ground (cf., e.g., Hopper 1998; Barlow-Kemmer 1999; Bybee 2006; 2007; CroftCruse 2004). ${ }^{8}$

In natural linguistics, the modelling of the linguistic system is not based on language use but the latter is taken into consideration in the psycholinguistic framing of the model (cf. Dressler et al. 1987, 8-9). In this paper, it is not our intention to build a usage-based grammar; we use the corpus as a source of examples, and in our conclusions we will lean largely on these materials.

The neologisms of HNC can serve as a useful basis for studying productivity in a practical sense, too: given that the two subcorpora serving as source of our data include an especially large number of words not yet included in commercial dictionaries, we can avoid having to base our conclusions on our own intuitions if we rely on them.

It can be hypothesised that the neologisms of HNC include realisations of a large number of potential words formed by productive rules since, in the case of productive derivations, it is in relatively large numbers that the derivates corresponding to systematic possibilities actually occur in language use. On the other hand, given that not all derivational neologisms are due to productive derivation, we can also assume that we would find neologisms in the corpus that analogically follow the individual models of various derivates. From the point of view of this study, such mechanisms of derivation (that cannot be seen as (fully) regular and hence cannot be taken to be productive, either) are also worth taking a

${ }^{8}$ Although most research in the framework of functional theories of language is of a qualitative nature at present, it has become possible, due to approaches devoted to usage-based grammars, to associate various trends in functional linguistics with corpus linguistics (with respect to cognitive linguistics, see e.g., Gries-Stefanowitsch 2006; Stefanowitsch-Gries 2006).

Acta Linguistica Hungarica 56, 2009 
look at, since the point of our project is exactly to determine which of the affixes we study are productive (to what extent) and which are not. There may be derivations following unique models at first that are subsequently organised into regular patterns and become productive as time goes by. We cannot exclude the possibility, either, that the productivity of the derivations under study here is evaluated vaguely or controversially in the literature exactly because some of these patterns are in the course of becoming regular.

Our study is not of a quantitative nature, we do not employ statistical analyses or frequency indices, and we use derivates occurring in $\mathrm{HNC}$ for illustrative purposes only ${ }^{9}$ however, on the basis of Bybee's arguments (cf. footnote 2), and despite the general view within Natural Morphology, we think it is worth considering and investigating whether type frequency or domain size has a role in the emergence and maintenance of productive patterns.

\section{On the productivity of some loan affixes}

In what follows, we will study four Hungarian noun-forming loan suffixes (-árium '-ar/-ary/-arium', -itás '-ity', -izmus '-ism', and -ista '-ist') in view of the above considerations, especially with respect to their productivity, via an analysis of data taken from HNC. Our choice is based on the fact that both -izmus and -ista are missing from the chapters on word formation (Keszler 2000b and Kiefer-Ladányi 2000b, respectively) of two recently published comprehensive grammars of Hungarian (Keszler 2000a and Kiefer 2000). In addition, Kiefer and Ladányi (2000b) discuss -itás but fail to mention -árium, whereas Keszler (2000b) covers -árium but neglects -itás. ${ }^{10}$

The Hungarian word final sequences -árium, -itás, -izmus and -ista were originally adopted in this language as parts of specific Latin words, subsequently becoming independent morphological objects (affixes) by

${ }^{9}$ Since, however, Natural Morphology claims that productive rules generate potential words that are not necessarily actualised in language use, it is not expedient to exclude constructed examples based on the rules established, either.

${ }^{10}$ On the other hand, all four suffixes occur in the chapter "Typical endings of loanwords as types of suffix" of Mártonfi (2007, 132-40), studying loan endings and their occurrences in a lexical corpus based on Laczkó-Mártonfi (2004, 132-40), refraining from taking sides with respect to the status or possible productivity of those endings. 
the help of which new words began to be created from loan stems coming from other languages: German, French (mainly mediated by German), or English (borrowed directly or indirectly), as well as, for some suffixes, from native Hungarian stems as well.

According to the literature on morphology, the word stock of a language can be classified into two large strata: native and non-native. It is also common knowledge that loan affixes preferentially attach to loan stems (Aronoff 1976; Dressler-Ladányi 1998; 2000; Kiefer-Ladányi $2000 \mathrm{~b}$ ). On the other hand, authors of papers written in the 1930s on Latinate affixes in Hungarian (for an overview, see Fludorovits 1937, ${ }^{11}$ cf. also Gyalmos 1933) only considered items that were able to create new words from native stems, too, to make up the set of 'Hungarian affixes of a Latin origin.. ${ }^{12}$ We will return to this issue below.

It is a common feature of the affixes studied here that, in cases where the base exhibits stem allomorphy, they invariably attach to the bound stem (e.g., Lakitelek-lakitelk-izmus 'name of a town in Hungary/a political trend associated with that town', forgalom-forgalm-ista 'traffic/traffic manager's assistant'). In addition, they may trigger vowel shortening, vowel deletion, or affix truncation even in cases where the base never exhibits the appropriate variant with native suffixes (this will be illustrated here by derivates involving the suffixes $-(a / o / e / \ddot{o}) s$ (adjective forming suffix), and -ság/-ség (noun forming suffix), respectively), ${ }^{13}$ e.g., Vatikán-vatikan-ista 'the Vatican/Vaticanist', but vatikán-os 'characteristic of the Vatican', Vasgárda-vasgárd-izmus 'the Iron Guard/the ideology of the Iron Guard', but vasgárdá-s 'characteristic of the Iron Guard', herbatea - herbate-ista 'herb-tea/one who often drinks herb-tea', but herbateá-s 'made with herb-tea', banális-banal-itás 'banal/banality', but banális-ság 'the quality of being banal', folklór-folklor-ista 'folk lore/a student of folk lore', but folklór-os 'having the quality of folk

${ }^{11}$ I wish to thank Zsuzsa C. Vladár for invaluable input on Latinate derivates in Hungarian, including her drawing my attention to Fludorovits' work in the first place.

12 The list of Hungarian noun forming suffixes of a Latin origin includes the following items in Gyalmos (1933) and D. Bartha (1958): -ista, -izmus, -tórium (-órium), -ia (-cia, -ánia, -ónia).

${ }^{13}$ From a typological viewpoint, these features are characteristic not of agglutinating but of inflecting-fusional languages; consequently, the Latinate component of Hungarian word formation contradicts the (mostly) agglutinating character of native Hungarian word formation. 
lore'. It is only in some of the most recent derivates that such stem allomorphy fails to occur (e.g., oportó-ista<oportó (a kind of wine), éjszaka-ista ${ }^{14}<$ éjszaka 'night'), but even then, both variants can be attested in most cases (e.g., iszlam-ista and iszlám-ista 'Islamist' ${ }^{15}<$ iszlám 'Islam', torgyan-izmus and torgyán-izmus $<$ Torgyán (a participant of Hungarian political life), tarantin-izmus and tarantinó-izmus $<$ Tarantino (in Hungarian, the name of the film director is pronounced - though not spelt — with long $o$ at the end).

\section{1. -(á)rium}

The ending -árium is not listed either in the literature from the 1930s referred to above or in D. Bartha (1958) as a Hungarian suffix of Latin origin, due to the fact that it did not occur with native stems at that time. Most examples collected from $\mathrm{HNC}^{16}$ are not neologisms either, but well-known loanwords from Latin, ${ }^{17}$ e.g., terrárium 'terrarium', akvárium 'aquarium', honorárium 'honorarium', kalendárium 'calendar', centenárium 'centenary', szeminárium 'seminar'. These words have assumed/retained various individual meanings in Hungarian; hence they do not allow us to establish a generalisable common meaning for Latinate words ending in -árium. However, there is a well-defined group of Latinate loans in which -árium has a constant meaning: 'the collection of something, the place where something is collected'. Instances include lectionárium 'collection of readings' (occurring in the corpus with this

14 This is probably partly due to the fact that, in these cases, derivates involving a truncated stem would be hard to recognise (*oport-ista) or easy to confuse with some other base (*éjszak-ista< <észak 'north', 'éjszaka 'night').

15 The vowel-shortening variants are sometimes preferred by Hungarian spelling conventions even in defiance of actual usage (Krisztina Laczkó, p.c.).

${ }^{16}$ Of the 130-140 -árium words collected from the two subcorpora of HNC and not occurring in printed dictionaries, a mere 8-10 items are neologisms; the others were borrowed into Hungarian as wholes. Only a handful of the neologisms involve native bases.

17 These occur in large numbers mainly as last constituents of compounds in Hungarian; for instance, the following compound initials occur with szeminárium 'seminar' as a compound final: adó- 'tax', bank- 'banking', diák- 'student', csoport- 'group', csúcs- 'top', dráma- 'drama', hittan- 'religious education', holocaust- 'holocaust', iszlám- 'Islam', pap- 'theological', párt- '(political) party', kontakt- 'contact', etc. 
mixed Latin-Hungarian spelling), evangeliárium 'gospel book, liturgical codex', legendárium 'collection of legends', vokabulárium 'vocabulary, list of words'. In some cases, due to the special character of the collection, the -árium word may mean 'institutionalised place', too. A good example is lapidárium 'museum of stonework finds'.

Most of the neologisms found in HNC are recent borrowings, mainly from English or German: szolárium 'solarium', hélárium 'solarium', biolárium 'biolarium', oceanárium 'oceanarium', delfinárium 'dolphin show'.18

Among neologisms involving -árium, just a handful of really new coinages occur whose bases are native Hungarian words: bronzárium 'solarium' < bronz 'bronze', morzsárium 'baker's shop' < morzsa 'crumbs', nektárium 'shop selling drinks' < nektár 'nectar', lekvárium 'shop selling jam, etc.' < lekvár 'jam'. In these forms, either the suffix is invariably -árium but then we must assume stem truncation as in nekt-árium, lekv-árium, morzs-árium, or else we could say that the suffix has several variants: -ium (nektár-ium, lekvár-ium), -rium (morzsá-rium), and -árium (bronz-árium).

In the above examples (coming from HNC and built on native bases), the meaning of -árium may be said to be constant and systematic: it adds the meaning component 'institutionalised place' to the items created by its help. That component may have emerged from the generalised meaning '(institutionalised) place' of some of the traditional Latinate loanwords ending in -árium and mentioned further above. The new derivates listed in the previous paragraph (similarly to those involving -da/-de, cf. Ladányi 2007, 132-42; 2008, 371-82), denote places where services are rendered or sales are performed. However, despite the constant meaning of -árium, the sense of the derived nouns is not transparent in most cases. (For instance, bronzárium 'solarium' denotes an institutionalised place, yet its meaning is merely associated to the base bronz 'bronze' via the bronze colour of tanned skin. Similarly, nektár 'nectar' or morzsa 'crumbs' obliquely refer to the nature of the goods (quality drinks and bakery products, respectively) offered for sale: nektár 'the drink of the gods' $\rightarrow$ 'divine drink' $\rightarrow$ 'drink that tastes divine' $\rightarrow$ 'good

${ }^{18}$ As a Google search reveals, szolárium and oceanárium also exist in English (solarium, oceanarium) and in a few other European languages; biolárium can likewise be attested in English (biolarium), as well as hélárium and delfinárium in German (Helarium, Delfinarium). The fact that these are not Hungarian derivations but are borrowed solid is shown by the non-occurrence of their bases or stems in Hungarian (e.g., in the case of szolárium or hélárium). 
quality drink'; cf. also the compound kenyérmorzsa 'breadcrumbs'. The meaning of lekvárium is more compositional, but it also takes extralinguistic knowledge to figure out: we have to infer that jams are not stored as a museum collection but are meant for sale.)

On the basis of these examples, especially lekvárium, we could assume that - provided the pattern were productive - the potential bases would be names of commercial goods, foodstuffs or drinks, just like in the case of $-d a /-d e$ items (cf. Ladányi 2007, 132-42; 2008, 371-82). However, the corpus does not include either loan-based items like ${ }^{*}$ szendvics-árium < szendvics 'sandwich', *likör-árium < likör 'liqueur', *hotdog-árium $<$ hotdog 'hot dog', or native-based items like *hus-árium $<$ hús 'meat', *kenyer-árium < kenyér 'bread', *ital-árium<ital 'drink'. Although Hungarian listeners would probably understand these non-existent Hungarian words on the basis of existing -árium words, they would take them to be funny, unique formations.

In these derivations individual models and surface analogy play a decisive role. Some of the novel derivates are variations on the word szolárium, borrowed earlier, and follow its individual model in terms of their form, too: hélárium, bronzárium, biolárium. ${ }^{19}$ The words hélárium and biolárium do not have common noun bases in Hungarian: bio- and helio- only occur as prefix-like compound constituents and Héliosz only occurs as a proper noun referring to the (Greek) god of the sun, not as a common noun. In the case of biolárium, the analogical transfer of the form of szolárium may be supported by a reanalysis of biológia 'biology' and/or szolárium: bio+lógia>biol+ógia, szol(ár)+árium > szo+lárium. In the examples involving native bases it is likewise conspicuous that two of them (lekvár, nektár) end in -ár to begin with, showing partial overlap with words in -árium, hence making analogy smoother.

In conclusion we can say the following. Despite the fact that new derivates involving this suffix do occur sporadically, even with native bases, we cannot (as yet) speak of productivity with respect to -árium in terms of the rule-based approach shared by Natural Morphology. The systematic meaning of this affix could, in the future, serve as a basis for its becoming regular, and then productive, but this is far from having happened: the present-day use of the affix -árium belongs to playful, non-

19 The expression summa summárium (also in the form szumma szummárium) occurring a few times in HNC in lieu of conventional Latinate summa summárum 'in sum, to summarise', also suggests the individual effect of -árium words. 
systematic word formation (just like the more widespread use of -da/-de, cf. Ladányi 2007, 132-42; Ladányi 2008, 371-82).

Nevertheless, we have to add that a theory based on analogy rather than on rules would resolve this issue in a different manner: such an approach (unlike rule-based theories) would treat regular and less regular mechanisms of word formation in a unified manner: it would invoke schemes all over the place, distinguishing them at most in terms of strength. Thus, in a scheme-based model, -árium would be assigned a weak analogical scheme on the basis of the constant meaning and recurrent form exhibited by the words containing it, and the sporadically occurring derivates would receive an explanation in terms of that weak scheme.

\section{2. - itás}

The affix -itás '-ity' occurs in the traditional stratum of loanwords in Latinate nouns (mainly occurring in parallel with the related Latinate adjectives). ${ }^{20}$ According to Kiefer-Ladányi (2000b, 167-8), this suffix derives nouns from loan adjectives and has a purely word-class-changing function. ${ }^{21}$ Kiefer and Ladányi additionally offer the following observations concerning this suffix: (1) -itás cannot be added to loan adjectives ending in -(iszt)ikus, -mán, -mer, -ózus; (2) adjectives ending in -is add -itás to their stem alternants lacking -is and involving a shortened vowel.

20 The material collected from the two subcorpora of HNC contains approximately 1200 words ending in -itás and not listed in ÉrtSz. Most of these are traditional Latinate loanwords and their compounds (e.g., with posterior constituents like -mentalitás 'mentality', -aktivitás 'activity', -kapacitás 'capacity', -intenzitás 'intensity', -stabilitás 'stability', -specialitás 'speciality'), or recent borrowings from German, French (via German), or English, used in Hungarian in a Latinised form. (These are borrowed in large numbers as part of scientific etc. terminology. Terms of this type used in linguistics, for instance, include velaritás 'velarity', szonoritás 'sonority' and szinonimitás 'synonymy'.) Hardly any real instances of -itás words (clearly not borrowed but derived from a potential or existing base within Hungarian) can be attested in this language; an example from the corpus is transzmédium-itás 'transmediality', used along with the borrowed item transzmedialitás.

${ }^{21}$ The affix -itás sporadically occurs on -is-final loan noun stems, too, as in admirális 'admiral' - admiral-itás 'admiralty'. An isolated new derivate in the corpus, based on a noun stem and hence quite irregular, is tabu-itás 'the quality of being taboo'. 
On the basis of the data taken from HNC, the above statements can be made more precise as follows. (1) The affix -itás also occurs with nouns ending in the sequences listed, e.g., misztikus 'mystic' - misztic-itás 'mysticism', humánus 'humane' - human-itás 'humanitarianism', polimer 'polymeric' - polimer-itás 'polymericity', porózus 'porous'-poroz-itás 'porosity'. The affix -itás attaches to the stem with its -is or -us truncated, and in the case of adjectives ending in -ikus (in addition to us being deleted) -ik changes to -ic, e.g., szinkronikus 'synchronic' - szinkronic-itás 'synchronicity', rusztikus 'rustic'-rusztic-itás 'rusticity'. (2) The stem vowel is shortened not only in stems involving a deleted -is (as in vizuális 'visual' - vizual-itás 'visuality', individuális 'individual' - individual-itás 'individuality'), but also in other cases like objektiv 'objective' - objektiv-itás 'objectivity', aktív 'active' - aktiv-itás 'activity', urbánus 'urban' urban-itás 'urbanity', morózus 'morose' - moroz-itás 'morosity'. ${ }^{22}$

Possible bases of twentieth-century derivations involving -itás are the various loan adjectives mainly coming from German or French (mediated by German, cf. Magyar 1932) and English. However, it was often the case that the corresponding nouns were also borrowed along with these adjectives, in a form adjusted to existing Latinate words. Due to the loan nouns, the appropriate -itás items were not derivable (lexical blocking, cf. Rainer 1988), ${ }^{23}$ e.g., bigott 'bigoted' - bigottéria 'bigotry' (< French/German bigot(t)-Bigo(t)terie), and not *bigott-itás, diszkrét 'discreet'-diszkréció 'discretion' (< French/German discret/diskret-Discretion), and not *diszkret-itás, impertinens 'impertinent' - impertinencia 'impertinence' ( $<$ French/German impertinent-impertinence/Impertinenz), and not *impertinent-itás.

Loan adjectives in -al or -bel/-ble are integrated into Hungarian with the Latinate form -ális and -bilis, respectively, and those in -ique/ -isch/-ic with the ending -ikus. In such cases, the corresponding noun also always exists in the source language (ending in -eté in French, -ität in German, and -ity in English). These nouns are borrowed into Hungarian with -itás, adjusted to the Latinate stratum of the word

22 See footnote 13 .

23 On the other hand, lexical blocking does not concern (or concerns to a lesser extent) the native affix -ság/-ség '-ness, -ity', deriving abstract nouns from adjectives with no restrictions: bigott-ság 'bigotry', diszkrét-ség 'discreetness', impertinens-ség 'impertinence'. 
stock, dropping the -is ending: ${ }^{24}$ banális 'banal' - banal-itás 'banality' (<French/German banal-French banalité, German Banalität), lojális 'loyal' - lojal-itás 'loyalty' (< German loyal-Loyalität), rentábilis 'lucrative' - rentabil-itás/rentábil-itás 'lucrativeness' (< German rentabel-Rentabilität), excentrikus 'eccentric' - excentric-itás 'eccentricity' ( $<$ French excentrique, German exzentrisch - French excentricité, German Exzentrizität).

In general, if the source language has the noun (ending in French -eté, German -ität, and English -ity, respectively) corresponding to a given adjective, the borrowed noun (irrespective of the form of the borrowed adjective) will take -itás in Hungarian (that is, what happens is not necessarily nouns being derived from the corresponding loan adjectives but rather the borrowing of similarly ending foreign nouns and adapting them to conform to the pattern of loanwords involving -itás), e.g., modernmodern-itás 'modernity', frivol 'frivolous' - frivol-itás 'frivolousness', naiv 'naive' - naiv-itás 'naivety', mobil 'mobile' - mobil-itás 'mobility', spontán 'spontaneous' - spontane-itás 'spontaneity', (cf. e.g., German Modernität, Souveränität, Frivolität, Naivität, Spontaneität). Of these examples, the form of spontaneitás is highly revealing: the stem form spontane- occurring before -itás suggests that the noun spontaneitás is not derived from the adjective spontán 'spontaneous' in Hungarian but is a Latinised form of German Spontaneität. ${ }^{25}$ It is also the case sometimes that Hungarian does not have the corresponding adjective at all, e.g., prior-itás 'priority', fragil-itás 'fragility', deform-itás 'deformity' but *prior(is), *fragil(is), * deform(is) - in such cases it is quite obvious that the noun can only have been borrowed (and integrated) as a whole.

In the case of loan adjectives that are not borrowed with one of the endings -is, -bilis, or -ikus and/or correspond to a noun in the source language that does not end in -eté/-ität/-ity, and alternative nouns with these endings cannot even be created in the source languages, the Hungarian noun corresponding to the given adjective will be derived by the native suffix -ság/-ség, and not -itás; e.g., elit 'élite'-*elit-itás, but elit-ség 'the quality of being élite', impozáns 'imposing'-*impozant-itás, but impozáns-ság 'the quality of being imposing', komplett 'complete' - *kom-

24 According to Mártonfi (2007, 140), too, -is and -itás are among the most frequent typical endings of pairs of loanwords sharing the same stem.

25 The form spontaneitás itself may also serve as a model followed by other items (at least as far as orthography is concerned): along with the usual form homogenitás 'homogeneity', the corpus also includes homogeneitás.

Acta Linguistica Hungarica 56, 2009 
plett-itás, but komplett-ség 'completeness', fitt 'fit' - *fitt-itás, but fitt-ség 'fitness', szingli 'single [unmarried]' - *szingl(i)-itás, but szingli-ség 'singleness'.

The affix -itás does not occur on Hungarian adjectives; it only occurs in the borrowed stratum of the Hungarian word stock, with the restrictions mentioned. As we saw, however, it plays a role in the Latinised integration of loan nouns ending in -ité, -ität, -ity, on the analogy of the original Latinate nouns in -itás. ${ }^{26}$ The suffix -itás is mainly capable of deriving nouns from borrowed adjectives that were Latinised with the ending -is, and of integrating nouns derived from them. It is difficult to tell whether in the case of relatively recent -itás neologisms we have to do with derivation or just the integration of the corresponding English nouns, e.g., virtuális - virtual-itás (< English virtual-virtuality), digitális-digital-itás (< English digital-digitality).

Given that the suffix -itás serves the integration of nouns ending in -ité/-ität/-ity and is also capable of deriving nouns in Hungarian, primarily from loan adjectives ending in $-i s,{ }^{27}$ it can be considered productive, even if in a very small range of cases and to a very limited extent.

\section{3. -izmus}

The suffix -izmus figures in the list of Hungarian noun-forming suffixes of a Latin origin (Gyalmos 1933; Fludorovits 1937), since it has been occurring ever since the 17th century, not only in Latinate but also in native Hungarian words (as we mentioned before, this was a criterion of being a suffix in the Hungarian literature between the 1930s and 1950s).

${ }^{26}$ Gyalmos (1933) calls this phenomenon "back-Latinisation"; Fludorovits (1937, 38) calls such words "pseudo-Latin or back-Latinised loanwords" and, referring to Tolnai, provides a list of back-Latinising endings, including -tás, serving to Latinise German words ending in -tät. Neither of them takes this ending to be a Hungarian suffix because it does not derive nouns from Hungarian adjectives. On the basis of more recent words like modern-itás 'modernity', frivol-itás 'frivolity', naiv-itás 'naivety', we take this element to be of the form -itás and, because of its (very limited) productivity, to be a suffix.

${ }^{27}$ It is possible to borrow and integrate such adjectives, even if in very limited numbers, see especially -al-final English adjectives (like digital and virtual, mentioned above). 
During the centuries, this suffix was being added, in diverse meanings, to certain characteristic groups of words: ${ }^{28}$

(1) 'Some linguistic peculiarity or a dialect and its use'. In this meaning, -izmus has been occurring with existing native bases like geographical names or names of peoples; e.g. ${ }^{29}$ Erdélyismus 'Transylvanism' $<$ Erdély 'Transylvania' (17th century), Germanismus 'Germanism' < germán 'German' (19th century), szegedizmus < Szeged (a town in SouthEastern Hungary), budapestizmus < Budapest (20th century). The potential bases, in this meaning of the suffix, are still geographical and ethnic names today.

(2) 'Some tenet, approach, theory, trend, etc. and its following; some (political) movement'. The literature of the thirties mentions the existence of plenty of back-Latinised French/German "guest words" in the 18th century in this meaning, illustrating them with examples like egoismus 'egotism', naturalismus 'naturalism', liberalismus 'liberalism', foederalismus 'federalism', etc. In the 19-20th centuries, we also find Hungarian derivations in this meaning, too, partly from loan bases (e.g., banditizmus 'banditism' < bandita 'bandit'), and partly from proper names (of politicians, e.g., apponyizmus $<$ Apponyi, bethlenizmus $<$ Bethlen).

Looking at the data gleaned from $\mathrm{HNC},{ }^{30}$ we see that -izmus neologisms do occur in the two meanings listed above, less so in the first ('some linguistic peculiarity or a dialect and its use'), and more so in the second meaning ('some tenet, approach, theory, trend, etc.; some movement'). In this latter meaning, the affix -izmus typically occurs attached to proper nouns, especially last names of persons; other bases include names of places or organisations associated with some ideology. For instance: kádár-izmus < Kádár (former politician), horn-izmus $<$ Horn, orbán-izmus < Orbán (politicians), döbrög-izmus $<$ Döbrögi, hábetler-izmus $<$ Hábetler (fictitious characters), lakitelk-izmus $<$ Lakitelek (an important location of the preparation of the 1990 political changes

28 The following brief summary is based on Gyalmos (1933) and D. Bartha (1958).

${ }^{29}$ Examples from before the twentieth century are cited with an obsolete orthography.

${ }^{30}$ In the two subcorpora of HNC we have looked at, approximately 1600-1700 words ending in -izmus occurred. Most of them are loanwords; many examples involve compounds with posterior constituents like -mechanizmus 'mechanism', -szocializmus 'socialism', -kapitalizmus 'capitalism', -imperalizmus 'imperialism', -liberalizmus 'liberalism', -rasszizmus 'racism', -nacionalizmus 'nationalism', etc. 
in Hungary), vasgárd-izmus < Vasgárda (Romanian chauvinist movement between 1927 and World War II).

Another part of the examples occurring in the corpus has a third, new meaning (based on the second) that can be illustrated by the following sample: hord-izmus < horda 'horde', család-izmus < család 'family', kutatóprogram-izmus < kutatóprogram 'research program', pógár-izmus < polgár 'citizen' (pógár is an ironically used non-standard pronunciation variant of polgár), prol-izmus < proli 'prole'. In these examples, the affix attaches to common nouns and the meaning of the derivates can be defined as follows: 'a certain mentality: strong attachment to some opinion or way of life (with an ironical connotation)'. This is a direct continuation of the second meaning mentioned above; the ironical overtone is based on the fact that the model opinion or way of life is not associated with a great artist, scholar, or ideologue but with an everyday pattern of behaviour that the language user does not wish to identify herself with, that she treats with ironical aloofness (családizmus, kutatóprogramizmus) or that she has a negative feeling about and that she smiles upon or laughs at (pógárizmus, prolizmus, hordizmus). That ironical perspective is especially clearly indicated by items whose pronunciation or spelling is non-standard (cf. pógárizmus).

The widespread use of -izmus in the stratum of loanwords is also supported by the fact that language users often resort to it even in cases where another word would be available, one that has a similar meaning but ends in another typical loan ending or suffix: -izmus $\sim$-ia: iron-izmus $\sim$ irón-ia 'irony', pártszimpat-izmus pártszimpát-ia 'party sympathy'; -izmus $\sim$-itás: produktiv-izmus produktiv-itás 'productivity', special-izmus special-itás 'specialty'. These examples suggest that -izmus has the typical productivity feature that it is capable of supplanting other loan suffixes of a similar function.

Furthermore, -izmus occurs in the neologisms of the corpus in the domain of native -ság/-ség and of the native combinations -os-ság/-es-ség and -z-ás/-z-és: -izmus $\sim$-ság/-ség: baloldal-izmus $\sim$ baloldali-ság 'leftism' < baloldali 'leftist', többség-izmus többségi-ség 'the property of belonging to the majority' < többségi 'majority (adj.)';1 -izmus $\sim$-os-ság/ -es-ség: humor-izmus humor-os-ság 'humorousness' < humor 'humour'; -izmus $\sim-\boldsymbol{z}$-ás/-z-és: lobb-izmus 'lobbyism'<lobbi 'lobby (noun)'

31 The suffix -izmus occurs in HNC even in cases where the corresponding word with -ság/-ség has a lexicalised meaning; e.g., szultánizmus 'sultanate' ( szultánság). 
lobbi-z-ás 'lobbying' < lobbi-z(-ik) 'lobby (verb)', brah-izmus 'daredevilism' < brahi 'daredevil behaviour' $\sim$ brahi-z-ás 'playing the daredevil' $<$ brahi-z(-ik) 'play the daredevil'. The morphological pattern anti-...-izmus is used equivalently with ...-ellenesség [morphological structure: ellen-es-ség] ${ }^{32}$ according to the corpus: anti-komcs(i)-izmus $\sim$ komcsi-ellenesség 'anticommunism' < komcsi 'commie', anti-párt-izmus párt-ellenesség 'anti-party-ism' < párt 'political party', anti-kisebbség-izmus kisebbség-ellenesség 'antipathy to minorities' < kisebbség 'minority'.

All of these examples have an ironical connotation-probably it is this additional shade of meaning that motivates the use of derivates involving -izmus. ${ }^{33}$

On the basis of our analysis of the examples taken from the corpus we can conclude that the affix -izmus is used systematically to derive new words from members of open lexical classes, in a regular manner (statable in morphological rules) and with a predictable meaning (compositionally), hence this suffix can be characterised as productive.

Further below, in the concluding section of this paper, we will return to the issue of what it means with respect to the productivity of such affixes that -izmus competes with other loan and native suffixes and is able to widen its domain at their expense.

\section{4. - ista}

According to the literature on loan affixes (cited above), -ista was widespread as early as in the Medieval Latin of Hungary, including ecclesiastical Latin. From the 17th century on, and especially, in large numbers, since the 18th century, -iste-final words borrowed from French via Ger-

32 By indicating the morphological structure of -ellenesség 'antipathy' I wish to suggest its relation to the correspondence between -izmus -os-ság/-es-ség, just mentioned.

33 Examples like humorizmus 'humourism', lobbizmus 'lobbyism', brahizmus 'daredevil-ism' that we initially interpreted as having -izmus to stand for a certain suffix combination in them, can also be analysed as deverbal derivates in which either the verb stem (being derived itself) or the suffix is truncated or they partly overlap: humor-izál 'crack jokes' (verb) $\rightarrow$ humor-izmus, humoriz-mus or humor-iz-mus, lobbi-z(-ik) 'lobby' (verb) $\rightarrow$ lobb-izmus, lobbiz-mus or lobb-iz-mus, brahi-z(-ik) 'play the daredevil' (verb) $\rightarrow$ brah-izmus, brahiz-mus or brah-iz-mus. However, derivates involving -izmus are typically not deverbal, a fact supporting the first interpretation.

Acta Linguistica Hungarica 56, 2009 
man were introduced into Hungarian in a form following earlier words directly taken from Latin ("back-Latinised"), ending in -ista (pronounced [isto], as opposed to present-day [ifto]; the original pronunciation was retained in words like masiniszta 'train driver', zsurnaliszta 'journalist', stiliszta 'stylist', statiszta 'crowd artist', soviniszta 'chauvinist'). ${ }^{34}$ In Gyalmos' (1933, 3) words, -ista "became a Hungarian suffix in the seventeenth century, and has been forming new words continually ever since".

Typically, this suffix forms nouns or adjectives from nouns. ${ }^{35}$ Traditional words involving it may have the following meanings (cf. Gyalmos $1933,3-14):{ }^{36}$

(1) 'follower of some tenet, approach, trend, etc.', e.g., anarch-ista $<$ anarchia 'anarchy', monarch-ista < monarchia 'monarchy', kossuth-ista $<$ Kossuth.

(2) 'expert/experienced in something' (musician, singer, actor, soldier, writer, scholar, civil servant, craftsman, player, athlete), e.g., brácsista $<$ brácsa 'viola', dalárd-ista $<$ dalárda 'choir', humor-ista $<$ humor 'humour', novell-ista $<$ novella 'short story', pentatlon-ista $<$ pentatlon 'pentathlon'.

(3) 'student', e.g., gimnaz-ista< gimnázium 'grammar school', kollég-ista $<$ kollégium 'college/student hostel';

34 The form of some words ending in -ista clearly shows that they are not derived from the corresponding noun but were borrowed in their entirety, e.g., impreszszionista 'impressionist' ( $<$ French impressionniste; the corresponding Hungarian noun is impresszió 'impression'), racionalista 'rationalist' (< French rationaliste; the corresponding Hungarian noun is ráció 'reason'). These words could be analysed as results of deadjectival noun formation in Hungarian, since -ista (just like -izmus) can form nouns out of adjectives as well as out of nouns, e.g., modern-modern-ista 'modernist', reális 'real' - real-ista 'realist'. Correspondingly: racionális 'rational' $\rightarrow$ racionalista 'rationalist', impresszionális 'impressionistic' $\rightarrow$ impresszionista 'impressionist'. However, the adjective impresszionális only occurs in the most recent internet sources-Google: 11 hits-, hence it cannot be the base of deadjectival derivation).

35 However, we will ignore denominal adjectives here.

36 The meanings of -izmus and -ista are partly parallel, resulting in their occurrence also being partly parallel. According to Mártonfi (2007, 140), too, -izmus and -ista are among the most frequent typical endings of pairs of loanwords sharing the same stem. The situation is similar to the case of English -ism and -ist (cf. Marchand 1969, 306-10). 
(4) 'member of a community, social class, corporate body, circle, society, etc.', e.g., akadém-ista < akadémia 'academy'.

Out of the -ista words occurring in the two subcorpora, ${ }^{37}$ some neologisms occur in one of the above traditional meanings. Possible bases of those occurring in meaning (1) above ('follower of some tenet, approach, trend, etc.') are primarily names of persons, institutions or social phenomena that imply some ideological commitment of their followers. Examples: vatikan-ista < Vatikán 'the Vatican', nagyimr-ista < Nagy Imre (a politician), peresztrojk-ista < peresztrojka 'perestroika', ludasmaty-ista $<$ Ludas Matyi (fictitious character/title of a humour magazine).

In meaning (2) ('expert/experienced in something'), the possible bases refer to genres, instruments, phenomena connected with the usual activity or job or expertise of the person concerned, e.g., vizuálpróz-ista $<$ vizuálpróza 'visual prose', kéjbord-ista (sic) < keyboard, kamer-ista < kamera 'video camera', mikrofon-ista $<$ mikrofon 'microphone', folklor-ista $<$ folklór 'folk lore', algebr-ista < algebra 'id..

In the novel derivates occurring in meaning (3) ('student'), possible bases refer to various forms of study: gim-ista $<$ gimi (diminutive of gimnázium 'grammar school'), kol-ista $<$ koli (diminutive of kollégium 'student hostel'), szakközép-ista<szakközép (abbreviated from szakközépiskola 'vocational secondary school') tanfolyam-ista $<$ tanfolyam 'course'.

With respect to meaning (4) ('member of a community, social class, corporate body, circle, society, etc.'), the determination of possible bases is semantically rather difficult, given that they may be connected with the activity of that community, too: galer-ista < galeri 'gang' (type of social organisation), but: agykontroll-ista $<$ agykontroll 'brain control', origam-ista < origami 'id.' (noun associated with the activity of the community).

In a special subtype (4/a) of the fourth meaning, it is easy to determine the range of possible bases. In this case, the base is the name of a sports club (especially football team), and the derived noun refers to a fan or rooter, e.g., ajax-ista $<$ Ajax, frad-ista $<$ Fradi (name of a Hungarian football team), vasas-ista $<$ Vasas (another Hungarian football team).

${ }^{37}$ In the two subcorpora of HNC we explored, roughly 3000 -ista words occur; most of them are widely known loanwords in Hungarian. 
We also find a new type of use, or a new meaning in the corpus. This new meaning is built on subtype (4a) mentioned above, with an extension of the notion of belonging to a fan club:

(5) 'somebody who is enthusiastic about something'. The corpus includes numerous instances of this new meaning, with both loan and native bases. Loan bases: hif-ista $<$ hifi 'high fidelity equipment', scif-ista $<$ scifi 'science fiction', hobb-ista < hobbi 'hobby'. Native bases (or old loan bases, not qualifying as foreignisms), with a joking/ironical shade of meaning: csokolád-ista < csokoládé 'chocolate'/ csok-ista $<$ csoki (abbreviated from csokoládé), divat-ista < divat 'fashion', herbate-ista $<$ herbatea 'herb-tea', növény-ista $<$ növény 'plant', vacs-ista $<$ vacsi (abbreviated from vacsora 'dinner'), cig-ista $<$ cigi (abbreviated from cigaretta 'cigarette'), bul-ista $<$ buli 'party, social gathering', moz-ista $<$ mozi 'cinema', oportó-ista $<$ oportó (a type of wine), éjszaka-ista<éjszaka 'night'.

HNC contains instances of -ista (similarly to those of -izmus) where the affix replaces other loan affixes or endings: dirig-ista vs. dirigens 'conductor (of an orchestra)', homoszexual-ista vs. homoszexuál-is 'homosexual', biolog-ista vs. biológ-us 'biologist', kém-ista vs. kém-ikus 'chemist'.

There are also cases in which -ista (added to or replacing the ending -or/-er originally meaning 'agent' in the source language) takes over, in some sense, the source-language function of the ending that is not recognisable in Hungarian: kurator-ista kurátor 'trustee' (< curator), szpiker-ista/szpik-ista szpíker 'announcer' (< speaker).

Furthermore, -ista turns out in the material of HNC to compete with the native noun/adjective forming suffix $-(a / o / e / \ddot{o}) s$ (cf. Kiefer-Ladányi 2000b, 189-91) hok-ista hoki-s 'hockey-player', államvédelm-ista államvédelmi-s 'state security officer', fidesz-ista fidesz-es 'member/supporter of a Hungarian political party', basszusgitár-ista basszusgitár-os 'bass guitar player', tax-ista $\sim$ taxi-s 'cab driver'. It can also be equivalent to the suffix combinations $-z-o-s /-z-o ̈-s$ or $-l-o ́-s /-l-o ̈-s:^{38}$ tap-ista $\sim$ tapi-z-ó-s $<$ tapi-z(-ik) 'grope, feel up' (verb), blog-ista ${ }^{39} \sim$ blog-ol-ó-s $<$ blog-ol 'blog' (verb), lejm-ista $\sim$ lejm-ol-ó-s $<$ lejm-ol 'ponce off sy'. ${ }^{40}$ The

38 Participles involving the suffix -ó/-ö combine with $-(a / o / e / \ddot{o}) s$ to refer to an activity seen as a constant property of the agent.

39 This example comes from Nóra Kugler (p.c.).

${ }^{40}$ Although the verbs blogol and lejmol have a loan stem (English blog (<weblog), German Leim as in jmdm. auf den Leim gehen 'sich von jmdm. überlisten lassen'), 
morphological structure anti-...-ista corresponds to compounds ending in ...-ellen-es: anti-csurk-ista Csurka-ellen-es 'opponent of Cs., a Hungarian politician', anti-magyar-ista $\sim$ magyar-ellen-es 'anti-Hungarian', anti-televiz-ista $\sim$ televízió-ellen-es 'one who never watches television', antiauto-ista $\sim$ autó-ellen-es 'one who never drives a car and dislikes other people doing so'. The use of -ista adds an ironical overtone in these cases, too.

\section{Degrees of productivity of loan affixes and the criteria of productivity}

The analysis of four loan affixes in the previous section has shown that they differ in terms of productivity. The present-day use of -árium follows a minor word formation pattern that cannot be stated in a rule and hence it is not productive, either, even though a group of the derivates formed with it exhibit a systematic meaning ('institutionalised place') and new coinages involving it sporadically occur. The suffix -itás only occurs in the borrowed stratum of the Hungarian word stock but it plays a role in the Latinised integration of loan nouns ending in -ité, -ität, -ity and is able to form nouns out of a group of loan adjectives (though, as we pointed out, it is difficult to tell in some cases whether it is an integrating suffix or a proper derivational suffix). Therefore, this suffix will be considered productive here, although its degree of productivity is low. As far as -izmus and -ista are concerned, the open classes of their potential bases are easy to define and the meanings of the derived nouns are predictable. Hence we take both suffixes to be productive. Both -izmus and -ista are capable of producing new words not only from loan bases but also from native ones. In these cases, the meanings of the derivates are shaded by irony; it is probably this additional connotation that motivates the use of these loan affixes with native bases, too.

In section 2.2, in connection with degrees of productivity, we have already mentioned that it is customary to take two criteria into consideration with respect to loan affixes (that mainly attach to items of the loan vocabulary): (1) their ability of integrating loanwords derivationally,

\footnotetext{
blog-ol ( $<$ Hungarian blog) is a derived and lejm-ol (Hungarian *lejm) is an integrated loanword in Hungarian. (Loan verb stems can be integrated into the Hungarian word stock only with Hungarian verb forming suffixes $-(a / e / o / \ddot{o}) l$ or -ál).
} 
and (2) their ability of attaching to integrated loanwords (cf. DresslerLadányi 1998, 45-6; 2000, 131-2). These two criteria can be applied easily to loan affixes that can only be associated with loan elements of the word stock, including, e.g., -itás. However, as we have seen, two of the three loan affixes that we found to be productive, -izmus and -ista, systematically attach to certain groups of native words, too. Hence, for these, the above two criteria are insufficient for establishing their degree of productivity.

We have also noted in section $\mathbf{2 . 2}$ that, were we to apply the productivity criteria originally proposed for native suffixes to loan suffixes, too, these criteria - in the ranking established for native suffixes - could not properly predict the decreasing degrees of productivity. This is because, in the case of loan suffixes, it is not ability to help loanwords fit into Hungarian and ability to attach to loanwords that are the least expected properties. Therefore, the system of productivity criteria has to be revised with respect to loan affixes in the spirit of the original proposal: the more serious difficulty a given affix can surmount, the more productive it is.

Accordingly, we propose the following set of criteria for establishing the degrees of productivity of loan affixes.

(1) The most productive set-similarly to native affixes - consists of affixes that can even be applied to abbreviations and acronyms, given that these are produced by extra-morphological means, and as such they are extraneous to the system (cf. Dressler-Ladányi 1998, 42; 2000, 122), e.g., stb.-izmus 'etc.-ism', fidesz-ista 'supporter of the political party called Fidesz, an acronym for "Young Democrats' Alliance" '.

(2) Less productive are the affixes that cannot be applied to abbreviations or acronyms but compete with native affixes, since this means that the affix extends its domain of application by intruding into that of a native affix. Among the four affixes studied here, there was none exhibiting exactly this degree of productivity: both -izmus and -ista can be applied to abbreviations and acronyms and they invade the domain of native affixes, too, e.g., többség-izmus többségi-ség 'majority-ism' < többségi, tap-ista $\sim$ tapi-z-ós 'one who likes to feel up' (tapi-z(ik) 'feel up').

(3) It appears that intruding into the domain of native affixes is only possible if the affix can also attach to native bases in its own derivational meaning, e.g., család-izmus 'family-ism' < család 'family', vacs-ista 'dinnerist, one enjoying dinners extremely' < vacsi (abbreviated form of vacsora 'dinner'). 
(4) An even lower degree of productivity can be attributed to affixes that cannot be attached to native bases but involve encroachment upon the domain of other loan affixes or (5) competition with other loan affixes or typical loanword endings.

The four affixes we studied did not include any exhibiting only degrees (4) and/or (5) of productivity; but good examples of rivalry between loan affixes include special-izmus 'specialism' $\sim$ special-itás 'speciality' (< speciális 'special') or kém-ista 'chemist' kém-ikus 'chemist' ( $<$ kémia 'chemistry').

(6) We take the productivity of a given affix even lower if it only attaches to integrated loanwords, e.g., digital-itás 'digitality' < digitális 'digital'; the base is an integrated form of English digital (provided we analyse the type digital-itás as being derivation proper, starting from Hungarian words of the digitális type, rather than direct integration of English digitality, cf. section 4.2).

(7) The lowest degree of productivity is the case where the loan affix is only capable to integrate loanwords into the Hungarian word stock. If we take e.g., digitalitás to be the result of derivation proper rather than direct integration of digitality, then -itás exhibits a higher degree of productivity than this; but Hungarian spontaneitás $<$ German Spontaneität (cf. Hung. spontán vs. * spontane-) is a good example of -itás functioning as a mere integrating affix, at least in some cases.

Using the above range of criteria, the three productive suffixes discussed in this paper exhibit the following properties with respect to the degree of productivity:

Table 1

\begin{tabular}{lllll}
\hline & & -itás & -izmus & -ista \\
\cline { 2 - 5 }$(1) \quad$ in abbreviations and acronyms & - & + & + \\
$(2)-(3)$ rivalry with Hungarian affixes, & & & \\
occurrence with Hungarian bases & - & + & + \\
$(4)-(5)$ shift of subclass or rivalry & & & \\
$\quad$ with loan affixes & - & + & + \\
$(6) \quad$ occurrence in integrated loanwords & $?$ & + & + \\
$(7) \quad$ integration of loanwords & + & + & + \\
\hline
\end{tabular}

Thus, in the case of loan affixes, the degree of productivity increases if (a) their use extends within the loan stratum of the vocabulary (by intruding into the domains of other loan affixes), (b) if it extends beyond 
the loan stratum and begins to involve native bases, too, and (c) if the loan affix concerned enters the domain of a semantically related native affix or affix combination. In all these three cases, it surmounts a higher degree of difficulty than if its use were restricted to the loan stratum or if within that stratum it only applied within its own original domain. Our claim that the productivity of loan affixes that also attach to native bases is higher is consistent with the point made in the Hungarian literature of the 1930s referred to above (cf. Gyalmos 1933; Fludorovits 1937) that the set of "Hungarian affixes of a Latinate origin" only includes affixes that are able to form new words from native elements of the word stock.

\section{Domain, type frequency, analogy, and productivity}

The approach of Natural Morphology takes domain restrictions in the case of rival affixes to be related to default status, ${ }^{41}$ but it does not take default status in itself to be an indicator of increased productivity, that is, the size of the domain of application is not one of its criteria for establishing degree of productivity.

But if - in accordance with the above considerations concerning loan affixation - the degree of productivity also depends on whether the given affix can extend its domain of application beyond its original limits, the degree (or increase) of productivity must also depend on the size (or growth) of the domain of application. In other words, unlike in the original view of Natural Morphology, we must conclude that domain size is also a factor contributing to the degree of productivity (similar results were also gained from our investigation of the native diminutive suffixes -ka/-ke and -cska/-cske, see Ladányi (2007, 153-82; 2008, 395-407) for the details). ${ }^{42}$

${ }^{41}$ For instance, in Hungarian diminutive formation, -cska/-cske and -ka/-ke are competing affixes. Diminutive formation involving -cska/-cske (or, the affix - cska/-cske itself) is the default, while the affix $-k a /-k e$ does not have that status, meaning that the latter affix can only be used under specific circumstances, while the former is not in general subject to such restrictions.

${ }^{42}$ In that study, -cska/-cske turned out to be more productive than -ka/-ke in terms of the system of criteria of Natural Morphology, but taking the individual criteria one by one we found that there was just a single clear case in which the difference in productivity between the two suffixes was indeed based on the given criterion and was not affected by domain differences. That case was the shift of subclass within diminutive formation that invariably happened in the 
Domain size is also related to the number of bases undergoing a given word formation rule: the larger the domain, the larger the number of items covered by the rule. Consequently, larger domain may also imply higher type frequency as an indicator of higher degree of productivity. This may be especially important in comparing the productivity of competing affixes. ${ }^{43}$

Word formation rules and their productivity both tend to change over time. New patterns that are in the process of being established are initially based on analogically followed individual models rather than productive rules. Among the loan affixes studied here, this stage is characteristic of the affix -árium. In some cases, the number of forms produced by such analogical processes begins to grow fast, that is, type frequency increases. Growing numbers of affixed forms are characteristic at present of the native affix $-d a /-d e$ 'shop, eating-place' (semantically akin to -árium): derivates are created on the basis of various analogical processes rather than clearly definable regular patterns but in deverbal derivation we can observe growing regularity and growing productivity, more so than in denominal cases (for the details, see Ladányi 2007, $132-42 ; 2008,371-82)$. It is our contention that the emergence of new productive rules is facilitated by the growing number of forms created by analogical processes, that is, the change of type frequency in general, too. Therefore, on the basis of Bybee $(2006 ; 2007)$ and deviating from the original view of Natural Morphology, we accept that type frequency (or more exactly, the growth of the number of words produced by following individual models) also plays a role in the emergence and maintenance of productive patterns. We assume the existence of a double mechanism

\footnotetext{
direction of -cska/-cske (e.g., nagynéni-ke> nagynéni-cske 'auntie, little aunt', but kapá-cska $>{ }^{*} k a p a ́-k a$ 'little hoe'). In addition, -cska/-cske applies to loanwords, acronyms, and abbreviations more unequivocally than $-k a /-k e$ does since, in these cases, there are certain phonological restrictions on the use of $-k a /-k e$. In our view, the last finding suggests that domain size (and, consequently, default status) does have an effect on the degree of productivity (pace the original claim of Natural Morphology) since the possibilities of the individual criteria playing a role are also determined by domain size.

${ }^{43}$ For instance, in the case of diminutive affixes, the type frequencies of the two affixes differed considerably in the two subcorpora studied: the set of derivates in -cska/-cske included over 2000 types, whereas derivatives in - $k a /-k e$ involved a mere 40-odd entries; in terms of token frequency the difference may be far smaller, given that the list of examples (with contexts) ran into 230 pages for -cska/-cske and 210 pages for $-k a /-k e$.
} 
in which higher type frequency can be derived from productive rules as potentialities, since productive rules are general mechanisms the (unconscious, automatic) following of which results in new words - but also, type frequency affects (facilitates or hinders) certain patterns becoming regular and productive, and helps productive patterns in maintaining their productivity.

\section{Conclusion}

In this paper, against the backdrop of the theoretical framework of Natural Morphology, we studied certain cases of noun formation of debated productivity, on the basis of a large number of data gleaned from two subcorpora of HNC. In particular, we were trying to find regular patterns of derivation in which affixes are attached to members of open lexical class(es) and produce derivates of predictable meaning. Of the loan affixes under study, we did not find word formation by -árium to be productive, but the affixes -itás, -izmus and -ista turned out to be productive, albeit to diverse extents.

In connection with those loan affixes, we considered the system of criteria of Natural Morphology concerning degrees of productivity, as well as peculiarities of the applicability of that system of criteria, and modified both the character and the rank order of those criteria. In addition, in the case of productive loan affixes, we concluded - deviating from the original view within Natural Morphology - that domain size and type frequency also affect the degree of productivity, a fact that has the further consequence that type frequency can be combined with the criteria of Natural Morphology and used as an indicator in establishing the degree of productivity, especially in cases where the emergence of a new productive rule or rivalry between competing affixes is at stake.

\section{References}

Aronoff, Mark 1976. Word-formation in generative grammar (Linguistic Inquiry Monographs 1). MIT Press, Cambridge MA.

Baayen, Harald 1989. A corpus-based approach to morphological productivity (Statistical analysis and psycholinguistic interpretation). Doctoral dissertation, Vrije Universiteit, Amsterdam.

Barlow, Michael-Suzanne Kemmer 1999. Usage-based models of language. CSLI Publications, Stanford. 
Bauer, Laurie 1983. English word-formation. Cambridge University Press, Cambridge. Bauer, Laurie 2001. Morphological productivity. Cambridge University Press, Cambridge.

Bauer, Laurie 2005. Productivity: Theories. In: Štekauer-Lieber (2005, 315-34).

Booij, Geert 1977. Dutch morphology. A study of word formation in generative grammar. Foris, Dordrecht.

Bybee, Joan L. 1988. Morphology as lexical organization. In: Michael HammondMichael Noonan (eds): Theoretical morphology. Approaches in modern linguistics, 119-141. Academic Press, San Diego.

Bybee, Joan L. 2006. From usage to grammar: The mind's response to repetition. In: Language $82: 711-33$.

Bybee, Joan L. 2007. Frequency of use and the organization of language. Oxford University Press, Oxford.

Croft, William - David Alan Cruse 2004. Cognitive linguistics. Cambridge University Press, Cambridge.

D. Bartha, Katalin 1958. Magyar történeti szóalaktan II: A magyar szóképzés története [Hungarian historical morphology vol. 2: The history of Hungarian word formation]. Tankönyvkiadó, Budapest.

Dressler, Wolfgang U. 1997. On productivity and potentiality in inflectional morphology (CLASNET Working Paper 7). Université de Montréal, Montreal.

Dressler, Wolfgang U. 1999. What is natural in natural morphology (NM)? In: Eva Hajičova-Tomaš Hoskovec-Oldřich Leška-Petr Sgall-Zdena Skoumalová (eds): Prague Linguistic Circle papers. Vol. 3, 135-44. John Benjamins, Amsterdam \& Philadelphia.

Dressler, Wolfgang U. 2000. Extragrammatical vs. marginal morphology. In: Ursula Doleschal-Anna M. Thornton (eds): Extragrammatical and marginal morphology, 2-10. Lincom Europa, Munich.

Dressler, Wolfgang U.-Mária Ladányi 1998. On grammatical productivity of word formation rules (WFRs). In: Wiener Linguistische Gazette 62/63:29-55.

Dressler, Wolfgang U.-Mária Ladányi 2000. Productivity in word formation (WF): A morphological approach. In: Acta Linguistica Hungarica 47 : 103-44.

Dressler, Wolfgang U.-Willi Mayerthaler-Oswald Panagl-Wofgang Ullrich Wurzel (eds) 1987. Leitmotifs in Natural Morphology. John Benjamins, Amsterdam \& Philadelphia.

ÉrtSz. = A magyar nyelv értelmező szótára I-VII. [A dictionary of the Hungarian language, volumes 1-7]. 1959-1962. Akadémiai Kiadó, Budapest.

Fludorovits, Jolán 1937. A magyar nyelv latin jövevényszavai [Latin loanwords in Hungarian] (A magyar nyelvtudomány kézikönyve [The handbook of Hungarian linguistics] Vol. 1., part 12.e.). Magyar Tudományos Akadémia, Budapest.

Gries, Stefan Th.-Anatol Stefanowitsch (eds) 2006. Corpora in Cognitive Linguistics. Corpus-based approaches to syntax and lexis. Mouton de Gruyter, Berlin \& New York.

Gyalmos, János 1933. Latin eredetű képzőink [Latin loan affixes in Hungarian] (A Magyar Nyelvtudományi Társaság kiadványai 31). Magyar Nyelvtudományi Társaság, Budapest.

Acta Linguistica Hungarica 56, 2009 
HNC = Magyar Nemzeti Szövegtár [Hungarian National Corpus]. (http://corpus.nytud.hu/mnsz)

Hopper, Paul J. 1998. Emergent grammar. In: Michael Tomasello (ed.): The new psychology of language. Cognitive and functional approaches to language structure, 155-75. Lawrence Erlbaum Associates, London.

Katamba, Francis 1993. Morphology. MacMillan, Houndmills \& London.

Keszler, Borbála (ed.) 2000a. Magyar grammatika [Hungarian grammar]. Budapest, Nemzeti Tankönyvkiadó.

Keszler, Borbála 2000b. Szóképzés [Word formation]. In: Keszler (2000a, 307-20).

Kiefer, Ferenc (ed.) 2000. Strukturális magyar nyelvtan 3. Morfológia [A structural grammar of Hungarian 3. Morphology]. Akadémiai Kiadó, Budapest.

Kiefer, Ferenc-Mária Ladányi 2000a. A szóképzés [Word formation]. In: Kiefer (2000, 137-64).

Kiefer, Ferenc-Mária Ladányi 2000b. Morfoszintaktikailag semleges képzések [Morphosyntax-neutral derivation]. In: Kiefer (2000, 165-214).

Laczkó, Krisztina - Attila Mártonfi 2004. Helyesírás [Spelling]. Osiris Kiadó, Budapest.

Ladányi, Mária 2007. Produktivitás és analógia a szóképzésben: elvek és esetek [Productivity and analogy in word formation: Principles and case studies]. Tinta Könyvkiadó, Budapest.

Ladányi, Mária 2008. Produktivitás és analógia a szóképzésben: a magyar főnévképzés néhány esete [Productivity and analogy in word formation: Some case studies in Hungarian noun formation]. In: Általános Nyelvészeti Tanulmányok 22 :349-430.

Lieber, Rochelle-Harald Baayen 1993. Verbal prefixes in Dutch: A study in lexical conceptual structure. In: Geert Booij-Jaap van Marle (eds): Yearbook of morphology 1993, 51-78. Kluwer, Dordrecht.

Magyar, Zoltán 1932. A magyarországi franciaság. Vie de mots Français en Hongrie [Le Français Magyarisé]. Debrecen sz. kir. város és a Tiszántúli Református Egyházkerület Könyvnyomda-vállalata, Debrecen.

Marchand, Hans 1969. The categories and types of present-day English wordformation: A synchronic-diachronic approach (Second, completely revised and enlarged edition). C. H. Beck, München.

Mártonfi, Attila 2007. A magyar toldalékmorfémák rendszere [The system of Hungarian affixal morphemes]. Doctoral dissertation, Eötvös Loránd Tudományegyetem, Budapest.

(http://martonfi.hu/phd/martonfi_attila___a_magyar_toldalekmorfemak_ rendszere.pdf)

Plag, Ingo 1999. Morphological productivity. Structural constraints in English derivation. Mouton de Gruyter, Berlin \& New York.

Plag, Ingo-Christiane Dalton Puffer-Harald Baayen 1999. Morphological productivity across speech and writing. In: English Language and Linguistics 3: 209-228.

Rainer, Franz 1988. Towards a theory of blocking: The case of Italian and German quality nouns. In: Geert Booij-Jaap van Marle (eds): Yearbook of morphology 1988, 155-85. Foris, Dordrecht. 
Rainer, Franz 2005. Constraints on productivity. In: Štekauer - Lieber (2005, 335-52). Schultink, Henk 1962. De morfologische valentie van het ongelede adjectief in modern Nederlands. Van Goor Zonen, den Haag.

Spencer, Andrew 1991. Morphological theory. An introduction to word structure in generative grammar. Blackwell, Cambridge MA \& Oxford.

Stefanowitsch, Anatol-Stefan Th. Gries (eds) 2006. Corpus-based approaches to metaphor and metonymy. Mouton de Gruyter, Berlin \& New York.

Štekauer, Pavol-Rochelle Lieber (eds) 2005. Handbook of word-formation. Springer, Dordrecht.

Tanos, Bálint 2008. Joan Bybee nyelvelmélete [Joan Bybee's theory of language]. In: Általános Nyelvészeti Tanulmányok 22 :537-66. 